\title{
INFORMATION MANAGEMENT AND COMMUNICATION TECHNOLOGY IN NURSING
}

\section{B. STEEN-NIELSSEN}

\section{OPSOMMING}

Inligting, en die benutting daarvan, is vandag baie belangrik en die rekenaar is een van die hulpmiddels wat moderne tegnologie beskikbaar gestel het om die groot hoeveelheid inligting te hanteer.

Daar is verskillende soorte rekenaars maar almal het dieselfde basiese eenhede. Deskundiges is nodig om die sagteware, of programme, te skryf. Die verpleegadministrateur en verpleegopvoeder hoef nie rekenaardeskundiges te word nie, maar moet die hulpmiddel verstaan om dit optimaal te kan benut in verpleegbestuur, die kliniese veld, navorsing en verpleegonderwys.

Die besluit om rekenaars te benut is ' $n$ dringende en noodsaaklike een. As verpleegkundiges nie self rekenaartegnologie op verpleegkunde toepas nie, dan sal ander dit doen.

\section{INFORMATION IS POWER}

Since World War II there has been an exponential increase in the amount of information of every kind. The question is how this information - whether scientific, commercial, clinical or educational can be captured and made easily available for retrieval, storage or research.

With the rapid expansion of communications technology this vast amount of information can now be disseminated to large and distant audiences as well as to the individual. Television, with its ability to reach large numbers of people, is a prime example of the use of communications technology. The development of media for the transfer or communicating of information for entertainment or educational purposes is a growth industry.

Information and the use of information is of great importance today. With the pace of life and the rapid increase of knowledge a person could be overwhelmed by this deluge of facts. The computer is one of the tools of modern technology which is available and capable of managing this enormous volume of information.

Today, students in some universities are writing what are known as open book examinations. The need is not just for the assimilation of facts and figures but the ability to use the information that is available. Students are not required merely to regurgitate information, they are being taught where to find it and how to use data.

\section{COMPUTER KNOW-HOW}

Computer technology is around us and in use in many areas that we already take for granted, for example:

digital watches

calculators

banking and building society ser-

vices

computer games

synchronisation of airline bookings

\section{Computicket}

The first digital computer was designed by Chas. Babbage (1791 - 1871), that is more than 100 years ago. It was very large and very expensive. His ideas were ahead of the technology available at that time.

With the advent of transistors and the silicone chip the size and cost of computers has gradually become much less, and is now within the reach of many more people and organisations.

\section{Types of computers}

Main frame computers refer to large expensive machines which require a carefully controlled environment.
Mini-computers are the size of an average filing cabinet and require no special environment.

Micro-computers are sometimes referred to as desk top computers and are about the size of an electric typewriter.

Other differences in computers are related to:

- the amount of information which can be stored in the memory

- the number of terminals which can be linked to the machine,

- cost

Computers store information and perform calculations and other functions many times faster than the human brain. It seems that the human brain can only process seven items of data at any one time.

Computers store information in binary code form but can supply information to the user in a form intelligible to him.

\section{Units of a computer}

The computer has the following units:

INPU'T UNIT - here information is translated from a collection of letters and numbers into the binary code; which is then transformed into a series of electrical impulses which are then directed to the storage unit.

STORAGE UNIT - here the electncal impulses are stored as a magnetic charge which can be held in store indefinitely until required. Computer programme instructions are stored in the same manner.

CONTROL UNIT - this is a highly complex master switch which controls the input, output, and other units by acting on instructions contained in the integral and user's programme 
ARITHMETIC UNIT - this unit carries out basic arithmetic functions as required.

OUTPUT UNIT - When the processing of information is completed, the electrical impulses produced must be fed to display units or printers. The output unit transforms the impulses to binary code form and ultimately to an alpha-numeric form which can be comprehended by the user.

Printers, video display units and back up storage units are often referred to as peripherals.

In practice the input, control, arithmetic and output units are physically integrated into a Central Processing Unit.

Information may be stored on punched cards or tapes with the larger machines or, increasingly today, on magnetic tapes or discs. This storage facility can be increased by interchanging tapes or discs, or by linking further tape or disc units to the computer. The computer and its associate peripherals are usually referred to as hardware.

\section{Computer Programs}

Software refers to the user's program. A program is a strictly logical sequence of instructions which the computer will follow in processing data. Before a program can be written the problem at hand must be carefully examined and analysed.

Writing computer programs requires very careful attention to detail which, with the shortage of skilled programmers, accounts for the high cost of commercially produced programs.

Programs need not follow a sequential pattern but can contain instructions to cause branching, or looping or repetition of a particular sequence as required, as often as required, and subject to conditions built in by the programmer.

Programming has been made a little easier since the advent of what are called high level languages. One such language is BASIC: Beginners All purpose Symbolic Instruction Code.

Basic is a complex but relatively easily learned language in wide use on microcomputers.
To summarise the functions of a computer:

First the recording of information -

Second the storing of data $\overline{\overline{M e m o r y}}^{\text {Input }}$

Third the processing of data -

Arithmetic

Fourth the retrieval of data $\overline{\text { Output }}$

Output

The Control Unit interprets and
instructs all the units regarding what to do and in what sequence it should be carried out. This procedure is highly skilled and requires a systems analyst and a professional programmer.

\section{COMPUTERS AND THE NURSE}

The nurse administrator and the nurse educator do not have to become computer experts, but the greater the understanding of the potential use of a computer in that particular area, the better she will be able to guide and advise the computer experts. It is essential for nurses to have some understanding of this tool for management, education and in clinical practice.

\section{Uses in nursing management}

In the administration of a hospital an efficient and effective method of handling information is vital. Essentially, in administration, records are kept:

- of patients - category, such as male/female or medical/surgical/gynaecological etc. - length of stay - ward or unit - accounts

- of staff - post occupied

- qualifications

- length of service

- previous experience

- record of training

- salary, pension, PAYE

- allocation to wards

- overtime

- sick leave, vacation leave etc

- of stock - ordered

$$
\text { - issued }
$$

- on the shelves

The nurse administrator could, using a computer, obtain a daily, weekly and monthly work load analysis of each and every ward/department.

This will require an indication on a daily basis of - the state of patient dependency
- the number of and expertise of each and every category of nurse in a department

- peak periods for the particular ward/department.

In other words, an indication is given of the category of staff actually required to give competent nursing care. Thus in nursing service management more cost effective use could be made of available manpower, based on scientific management principles.

As regards stock control, analyses could be undertaken of volume and patterns of usage in each and every department.

Stock losses and replacement can be accurately pinpointed. With the mounting costs of delivering an effective health service the nursing service manager must make the best use of manpower and materials.

\section{Uses in the clinical field}

Looking at the clinical field, the emphasis has been on the use of computers in highly specialised units, such as in intensive nursing care, for recording, storage and retrieval of clinical data from the automated electronic equipment.

Making greater use of the computer, with terminals at least in every ward which are linked to all other departments, the professional nurse should be able to obtain a full clinical history, medical and nursing, as well as data from the laboratories, X-Ray department and pharmacy. Current medical treatment and current progressive nursing observations, treatment and patient responses could also be computerised.

With a computer link it should further be possible to obtain data regarding the attendance of the patient at the out-patient department or day hospitals. In other words, all patient data could be available throughout the health service system.

Just imagine the patient presenting his magnetised plastic card, of the type now in use at banks and building societies, for a complete and up to date printout of his medical history being immediately available. Think of the saving in time and materials by eliminating duplication and storage of thousands of files and folders. 


\section{Nursing informatics}

This term, coined by computer professionals, is used to describe the combination of information technology and systems thinking. Computer nursing systems are becoming imperative in the health care services for financial reasons. Nurses form the largest group of professionals in the system.

Therefore the cost effective use of available personnel is essential and the immediacy of information on the patient and his condition is vital. Evidence of the quality of nursing care and control of patient services and environment are also necessary.

\section{Research}

As a tool in the hands of a competent manager, the computer can be of great assistance for:

- investigation of problems such as — absenteeism

- outbreaks of infection

- other medico-legal hazards such as patterns of injury to patients and staff

- analysis of supplies

- disposable

- perishable

- analysis of patient environment

- analysis of the role and function of each category of nurse as well as identification and classification of the functions essential for/ expected of a particular dependency rating.

The computer could aid in isolating and specifying the observable and measurable functions for each level of dependency. Analysis of applicants for training and the development of a personality profile which could aid selection is also possible with a computer.

\section{Computers in nursing education}

The trend today in nursing education is that of resource-based learning. There are a multiplicity of resources available such as: slide/tape programmes, charts, models, specimens, films, television, books, learning packages (for example modules), tapes, and computers, one of the newest of the resources.

Computers are not the beginning and the end in education but they do have great, as yet untapped, potential to aid the learning process.
They are tools of great value in the hands of an experienced educator. She does not need to fear computers. On the contrary, they can be of great assistance by being programmed to take over the repetitious and purely factual delivery of information. The educator is then free to give guidance to the rapid learner and has time to assist the slower learner. The educator is able to give individual attention to the student.

\section{Curriculum}

The use of the computer in nursing education starts with a careful analysis of the curriculum. The role of the nurse in training must be stated explicitly in terms of objectives. These objectives can be further clarified in terms of cognitive, conative and psychomotor skills.

Each objective can then be viewed in terms of where the computer can provide the best available learning experience for the particular section of work. Systematic analysis of learning objectives and of the most appropriate resources to assist the student to achieve competency, is now possible.

With resource-based learning the role of the student changes from one of passivity to active involvement. At the commencement of her training she could be presented with the overall objectives as well as the mini-objectives for each year. It can then be stated precisely how these objectives may be achieved, for example by:

- clinical experience

- slide/tape programs

- criterion reference charts

— information sessions

- modules

- computer sessions including multiple choice questions, factual information, problem analysis, designing of care plans.

The student is now directly and actively involved in the learning process. She is given the goal to be achieved and she is shown how this may be reached. She is treated as an adult responsible for her chosen career, supported by the team consisting of the tutor, the clinical educator, the lecturer, the ward sister and zonal matron.

There is now co-responsiblity for making the maximum use of all learing experiences in the clinical situation.

\section{Advantages of computer as- sisted learning}

Computer assisted learning is a way of teaching and learning by computer which can be adapted to individual needs. Among the advantages are the following:

- There is immediate feedback of student responses. Active involvement cannot be avoided and the immediate response seems to produce the motivation to beat the machine.

- Interactive learning. Computer assisted learning offers personalised, individual tutorials which provide for the assessment of the student's knowledge and understanding throughout each and every program.

- Individualised instruction. One of the very real problems facing any tutor is the great variety of background and ability of each and every student. Computer assisted learning provides a one-toone communication system which is at the convenience of the student. Any programme may be repeated by her as frequently as necessary, without fearing peer or tutor censure. The computer also records student responses during instruction so that weaknesses and strengths may be identified.

- Availability. Computer assisted learning programs are available at all times, day or night, wherever the nurse is situated. Student-tutor contact is limited by factors such as the size of the class, night-duty and shortage of tutors.

\section{The changing role of the tutor}

With the addition of computer programs to her armoury of resources, the tutor now becomes a manager of learning experiences and resources which are preplanned to enable the student to achieve the pre-stated objectives.

The tutor herself becomes, or should become, another flexible and available resource 
- to guide and direct the student

- to present her with new challenges in problem solving

- to assist, to explain, and to encourage

- to provide the educational framework for learning experiences that will aid the student in taking and making decisions affecting the care of her patient.

\section{Implications}

Some of the possible implications of the use of computers in nursing education are that the brighter student may well complete all requirements for the course in less than the stipulated time whereas the slower student may take slightly longer than the prescribed length of the course. Both will however have completed the required criteria.

Competent practitioners of nursing will be available to the health services as soon as they have completed all cognitive, conative and psycho-motor objectives. With computer-aided learning the training and education of the nurse could be made more cost-effective

Computers in nursing education also imply student satisfaction with preparation for her professional role. It assists her to recognise her responsibility and accountability as a practitioner of nursing.

\section{DECIDING TO USE COMPUTERS}

The decision to make use of computers in nursing education is a very urgent and important one facing the responsible authorities. Consideration should be given to various aspects.

First, in the long term planning for nursing education, how far should one look ahead with computers in mind? Technology is changing rapidly and constantly, therefore the initial equipment should be capable of being added to, to meet educational needs without costly replacement of the control units. In other words the system must be reasonably adaptable and flexible and able to grow with improvements and user demands.

Not only must the computer be capable of performing a multitude of educational programs but should also be capable of recording the administrative facets of nursing educa- tion, such as marks, programs completed or still to be completed.

In our short-term planning it must be decided what system could be introduced which is compatible with existing computer facilities, what would be needed in the way of additional terminals, and desk top units which are cable links to other centres.

Cost is an important consideration as are the maintenance, repair and back-up services which must be available locally, or at least in this country

Software is an important aspect, not only as regards the designing of courseware, but also for the costs involved in for example printer, paper, discs and time.

Compatibility of program language used must be kept in mind when considering the purchase of programmes from other centres or countries. Because of the great variety of computers available a careful analysis of exactly what the user wants the computer to be able to do, must be carried out. This will include analysis of the types of educational programmes, for example multiple choice, problem solving, analysis, research, branching, looping or remedial programs, graphics and the administrative record keeping for each student. The computer design team should consist of a systems analist, a programmer, a nurse educator and a nurse administrator. The designing of courseware is an urgent priority if computers are to be introduced and used as effectively as possible. Program design takes time and the best tutors/lecturers should be involved in the development of the courseware. The content of the programs should be derived from the objectives specified in the curriculum.

Once programs are produced they can be made available throughout the province and the country. Thus a standard of education can be stated for the student, no matter where she is based. The student does not necessarily have to leave the smaller hospitals to obtain comparable educational opportunities to those available in the larger centres. Teletuition is now possible with computer/telephone cable/video display unit link-up.

\section{CONTINUING EDUCATION}

Ensuring the competency of all categories of staff is becoming an increasingly important responsibility of the employing authorities. The patient today is very aware of his rights and he is also very conscious of the cost of health services. Those responsible for the management of health services must thus attempt to maintain and improve the competency of their staff. They may be held responsible for the employment of staff who are not safe and competent practitioners of nursing.

The computer could play an extremely important role in this regard in

- pre-testing of applicants, whether students or qualified practitioners

- orientation programs for new staff members of all categories

- continuing education courses as a mandatory requirement of employment.

This trend in large organisations implies that, though the professional is herself accountable for her own actions, the employer can also be held responsible if no proof of competency with regard to patient care can be demonstrated.

\section{CONCLUSION}

The professional nurse today is increasingly facing a huge volume of information. The computer can help to sift and analyse the data so that she can make decisions based on accurate and relevent information.

Much careful thought and planning must be given to the type of system to be used and how it should be programmed. Both the time and money spent in a thorough analysis of the problem will be a real investment in the future of professional nursing.

A thought worth remembering comes from a conference held in London last year entitled The Impact of Computers on Nursing:if nurses do not apply computer technology to nursing, others will.

We must prepare now to use this technology to meet our clinical, management and educational needs. 